\title{
Pengaruh Konsentrasi IgY Induk yang Berbeda Terhadap Gambaran Darah Anak Ayam Sentul
}

\author{
Melly Pratiwi Setyawati ${ }^{1 *}$, Niken Ulupi ${ }^{1}$, Sri Murtini ${ }^{2}$ dan Cece Sumantri ${ }^{1}$ \\ ${ }^{1}$ Program Studi Ilmu Produksi dan Teknologi Peternakan, Fakultas Peternakan IPB \\ ${ }^{2}$ Program Studi Mikrobiologi Medik, Fakultas Kedokteran Hewan, Institut Pertanian Bogor, \\ Jl. Agatis Kampus IPB Dramaga, Bogor 16680 \\ *Email koespondensi: mellypratiwi110@gmail.com
}

(Diterima: 02-03-2019; disetujui 30-04-2019)

\begin{abstract}
ABSTRAK
Penelitian ini bertujuan untuk menganalisis gambaran sel darah putih dan sel darah merah sebagai indikator ketahanan tubuh pada anak ayam sentul. Penelitian ini menggunakan 20 ekor ayam betina dan 20 ekor ayam jantan yang dikawinkan, masing masing terdiri dari 10 ekor ayam dengan konsentrasi IgY tinggi dan 10 ekor ayam dengan konsentrasi IgY rendah. Berdasarkan hasil perkawinan tersebut diperolah 34 ekor anak ayam yang terdiri dari 17 ekor anak ayam yang berasaldari induk dengan konsentrasi IgY rendah. Parameter yang diamati meliputi gambaran sel darah merah (eritrosit, hematocrit dan indeks eritrosit) dan gambaran sel darah putih (leukosit dan diferensiasinya). Penelitian ini menggunakan rancangan acak lengkap (RAL) dengan 2 perlakuan, semua perlakuan diulang 10 kali. Data yang diperoleh dianalisis menggunakan t-test program SAS. Hasil penelitian ini menunjukan bahwa perbedaan konsentrasi IgY pada induk tidak mempengaruhi sel darah merah dan sel darah putih. Namun terdapat kecendrungan nilai limfosit yang rendah dan H/L yang tinggi pada anak ayam yang berasal dari induk dengan konsentrasi $\operatorname{IgY}$ rendah. Hasil ini mengindikasi bahwa anak ayam yang berasal dari induk dengan konsentrasi IgY rendah lebih rentan terhadap cekaman panas.
\end{abstract}

Kata Kunci: ayam sentul, IgY, gambaran darah, ketahanan tubuh

\begin{abstract}
This study was to aim the description of white blood cells and red blood cells as indicators of immunity in Sentul chicks. This study used 20 hen chickens and 20 cock-chicken mated, consisting of 10 chickens with high IgY concentration and 10 chickens with low IgY concentrations. Based on the results of mating, 34 chicks were obtained consisting of 17 chicks that were from the hen with low IgY concentration. The parameters observed included the description of red blood cells (erythrocytes, hematocrit and erythrocyte index) and the description of white blood cells (leukocytes and their differentiation). The experiment was conducted as a completely randomized design with 2 treatments, all treatments were repeated 10 times. The data obtained were analyzed using the SAS program t-test. The results of this study indicate that the difference in IgY concentration in the hen did not effect on red blood cells and white blood cells. However, there is a tendency for low lymphocyte values and high $\mathrm{H} / \mathrm{L}$ in chicks originating from hens with low IgY concentrations. These results indicate that chicks from hens with low IgY concentrations are more susceptible to heat stress.
\end{abstract}

Keyword: blood picture, IgY, immunity, sentul chicken

\section{PENDAHULUAN}

Ayam sentul merupakan ayam lokal yang memiliki produktivitas tinggi (telur dan daging) sehingga memiliki potensi untuk dikembangkan. Salah satu yang menjadi permasalahan pada pengembangan ayam lokal adalah mortalitas yang tinggi pada saat pemeliharaan. Upaya yang dilakukan untuk meningkatkan populasi ayam lokal adalah memproduksi ayam lokal dengan tingkat kesehatan (fitness) yang baik. 
Peningkatan produktivitas ayam tidak cukup hanya dengan perbaikan pakan dan manajemen pemeliharaan, tetapi perlu dilakukan peningkatan mutu genetiknya dengan mempertahankan sifat-sifat khas fisiologi tubuh ayam tersebut. Salah satu parameter fisiologis tubuh yang mencerminkan kondisi ternak unggas (ayam) adalah gambaran darah. Darah merupakan komponen yang mempunyai fungsi yang sangat penting dalam pengaturan fisiologis tubuh dan media transport yang paling penting hampir semua fungsi tubuh. Salah satu indikator untuk menentukan tingkat kesehatan tersebut adalah dengan melihat profil darah pada keturunan yang dihasilkan (Guyton \& Hall, 1997).

Regar et al. (2013) menyatakan bahwa ternak yang memiliki ketahanan tinggi (IgY total tinggi) menghasilkan performa produksi yang baik. IgY merupakan maternal antibodi yang diperoleh dari induk ke anaknya pada saat inkubasi. IgY berperan dalam melawan patogen yang dapat menginfeksi pada anak ayam. IgY yang tinggi pada induk diharapkan dapat menghasilkan anak dengan tingkat ketahanan tubuh yang baik. Setyawati et al. (2019) melaporkan bahwa ayam dengan konsentrasi IgY tinggi memiliki ketahanan tubuh yang tinggi dalam melawan paparan patogen. Konsentrasi IgY yang tinggi pada induk ini diharapkan akan menghasilkan keturunan dengan ketahanan tubuh yang juga tinggi. Ketahanan tubuh yang tinggi tergambar dari parameter fisiologis gambaran darah anak ayam yang dihasilkan.

\section{MATERI DAN METODE}

\section{Materi Penelitian}

Induk ayam yang digunakan sebagai penelitian merupakan ayam hasil seleksi yang berasal dari Fakultas Peternakan Insitut Pertanian Bogor. Pengujian konsentrasi $\operatorname{IgY}$ dilakukan pada 20 ekor ayam sentul betina dan 20 ekor ayam jantan. Selanjutnya total IgY dari keseluruhan sampel dirata-ratakan. Total ratarata IgY serum pada induk adalah $9.55 \pm 1.25$ $\mathrm{mg} \mathrm{ml}^{-1}$. Ayam yang memiliki konsentrasi IgY diatas jumlah total rata-rata $(>9,55 \pm 1,25 \mathrm{mg}$ $\mathrm{mL}^{-1}$ ) dikelompokan sebagai ayam dengan konsentrasi IgY tinggi, sedangkan ayam yang memiliki konsentrasi IgY sama atau dibawah total rata-rata $\left(\leq 9,55 \pm 1,25 \mathrm{mg} \mathrm{ml}^{-1}\right)$ dikelompokan sebagai ayam dengan konsentrasi IgY rendah. Ayam jantan dengan konsentrasi $\operatorname{IgY}$ tinggi dikawinkan dengan ayam betina yang memiliki konsentrasi IgY yang tinggi pula. Pengujian total IgY dalam serum dilakukan dengan menggunakan metode indirect ELISA menurut Yokoi et al. (2002). Berdasarkan hasil perkawinan tersebut diperoleh 34 ekor anak ayam sentul yang terdiri dari 17 ekor anak ayam yang berasal dari induk dengan konsentrasi tinggi dan 17 ekor anak ayam yang diperoleh dari induk dengan konsentrasi IgY rendah. Pemeliharaan anak ayam yang akan diamati dilakukan dikandang khusus brooder dan diberi pakan komersil broiler periode starter dengan kandungan protein $21,5-23,8 \%$ dan energi metabolis 3025 $3125 \mathrm{Kkal} \mathrm{kg}^{-1}$.

\section{Metode Penelitian}

Pengambilan sampel darah dilakukan pada anak ayam yang dihasilkan dari masingmasing kelompok pada umur 2 minggu. Darah diambil pada vena brachialis, tersebut dimasukkan ke dalam vaccum tube EDTA-K2. Sampel darah tersebut langsung dimasukkan ke dalam ice box dan dibawa ke Laboratorium Fisiologis, FKH IPB. Selanjutnya dilakukan pemeriksaan gambaran darah merah dan darah putih.

Gambaran darah yang diukur adalah sel darah merah (eritrosit) meliputi konsentrasi eritrosit, hematokrit, hemoglobin. Gambaran sel darah putih meliputi konsentrasi leukosit dan persentase diferensiasinya yaitu limfosit, monosit, heterofil, eosinofil, dan basofil. Pengujian gambaran darah tersebut dilakukan berdasarkan Sastradipraja et al. (1989).

\section{Rancangan Penelitian}

Rancangan yang digunakan adalah rancangan acak lengkap (RAL) dengan dengan 2 perlakuan yaitu anak ayam yang berasal dari induk dengan konsentrasi IgY tinggi dan anak ayam yang berasal dari induk ayam dengan konsentrasi IgY rendah, semua perlakuan diulang sebanyak 10 kali. Semua data peubah yang diperoleh dianalisis menggunakan uji-t program software SAS 9.0 dengan rumus sebagai berikut:

$$
\mathrm{t}=\frac{\bar{x}_{1}-\bar{x}_{2}}{\sqrt{\frac{\left(n_{1}-1\right) s_{1}^{2}+\left(n_{2}-1\right) s_{2}^{2}}{n_{1}+n_{2}}\left(\frac{1}{n_{1}}+\frac{1}{n_{2}}\right)}}
$$

Keterangan:

$$
\begin{aligned}
& \mathrm{n}_{1}=\text { jumlah pengamatan sampel dengan } \\
& \mathrm{n}_{2}=\text { jonsentrasi IgY tinggi } \\
& \text { jumlah pengamatan sampel dengan }
\end{aligned}
$$




$$
\begin{aligned}
& \text { konsentrasi IgY rendah } \\
& \bar{x}_{1}=\text { rataan sampel sampel anak ayam } \\
& \text { dari induk konsentrasi Ig Y tinggi } \\
& \bar{x}_{2}=\text { rataan sampel anak ayam dari induk } \\
& \text { konsentrasi IgY rendah } \\
& \mathrm{s}_{1}=\text { standart deviasi sampel anak ayam } \\
& \text { dari induk konsentrasi IgY tinggi } \\
& \mathrm{s}_{2}=\text { standart deviasi sampel anak ayam } \\
& \text { dari induk konsentrasi IgY rendah }
\end{aligned}
$$

\section{HASIL DAN PEMBAHASAN}

Darah memiliki fungsi sebagai alat transportasi dan ketahanan tubuh. Darah terdiri atas cairan berupa plasma (55\%) dan padatan (45\%). Darah terdiri sel darah merah dan sel darah putih. Pembentukan darah terjadi di sumsung tulang (Ulupi \& Ihkwantoro, 2014).

\section{Gambaran Darah Merah}

Hasil pengujian konsentrasi eritrosit, hematokrit, hemoglobin, serta indeks eritrosit anak ayam yang berasal dari induk dengan konsentrasi IgY tinggi dan rendah disajikan pada Tabel 1 .

Tabel 1. Gambaran sel merah anak ayam sentul selama penelitian

\begin{tabular}{lrrr}
\hline \multirow{2}{*}{ Peubah } & \multicolumn{2}{c}{ IgY Induk } & \multirow{2}{*}{ Standar } \\
\cline { 2 - 3 } & Rendah & Tinggi & \\
\hline Eritrosit & $2,51 \pm 0,28$ & $2,60 \pm 0,40$ & $2,5-3,5^{1}$ \\
$\left(10^{6} \mathrm{sel} / \mathrm{mm}^{3}\right)$ & & & \\
PCV $(\%)$ & $23,36 \pm 3,61$ & $24,93 \pm 3,55$ & $22-35^{1}$ \\
Hemoglobin & $11,15 \pm 2,02$ & $12,01 \pm 1,45$ & $7-0-13,0^{1}$ \\
$(\mathrm{~g} / 100 \mathrm{ml})$ & & & \\
\hline Sumber: ${ }^{1}$ Weiss \& Wardrop (2010) &
\end{tabular}

Eritrosit mengandung hemoglobin yang berperan sebagai alat transportasi oksigen dari paru-paru ke sel dan membawa karbondioksida dari sel ke paru-paru Wientarsih et al. (2013). Hasil penelitian ini menunjukan perbedaan konsentrasi IgY pada induk tidak berpengaruh terhadap nilai eritrosit darah anak ayam yang dihasilkan. Nilai eritrosit yang dihasilkan pada anak ayam kedua perlakuan berada dalam kisaran normal. Nilai eritrosit tidak berbeda dalam penelitian ini disebabkan ayam dalam kondisi pemeliharan yang sama, baik suhu maupun pakan yang diberikan. Hal ini sesuai dengan hasil pernyataan (Banergee et al., 2002). Bahwa salah satu faktor yang mempengaruhi pembentukan eritrosit adalah kecukupan nutrisi pakan.

Persentase sel darah merah dalam $100 \mathrm{ml}$ darah dinamakan hematokrit atau packed cell volume (PCV). Perbedaan konsentrasi IgY pada induk tidak memberikan pengaruh terhadap nilai hematokrit anak ayam yang dihasilkan. Nilai hematocrit pada kedua anak ayam berada dalam kisaran normal. Rastogi (2007) mengatakan nilai hematokrit rendah mengindikasikan terjadinya anemia atau overhidrasi. Nilai hematocrit yang normal tidak mengindikasi adanya ganguan anemia atau overhidrasi pada anak ayam yang dihasilkan. Kondisi lingkungan yang sama menyebabkan nilai hematocrit pada penelitian ini tidak berbeda. Hal ini sesuai pernyataan Altan et al. (1999) bahwa kondisi lingkungan sangat mempengaruhi nilai hematocrit terutama suhu lingkungan. Pemeliharaan pada suhu tinggi menyebabkan nilai hematokrit menurun.

Nilai hemoglobin pada kedua perlakuan tidak berbeda secara statistik. Hemoglobin umumnya berbanding lurus dengan nilai eritrosit, sehingga nilai eritrosit yang tidak berbeda menyebabkan nilai hemoglobin yang dihasilkan juga tidak berbeda. Hemoglobin merupakan senyawa yang berasal dari ikatan komplek antar protein dan $\mathrm{Fe}$ yang menyebabkan warna merah pada darah (Wientarsih et al., 2013).

\section{Gambaran Sel Darah Putih}

Leukosit merupakan sel-sel yang dapat digunakan untuk mengestimasi potensi ketahanan tubuh. Leukosit berdiferensiasi menjadi beberapa sel yaitu heterofil, limfosit, monosit, eusinofil dan basofil. Analisis leukosit dan diferensiasi leukosit anak ayam sentul hasil penelitian disajikan pada Tabel 2.Hasil penelitian ini menunjukan bahwa perbedaan kosentrasi $\operatorname{IgY}$ pada induk tidak berpengaruh terhadap nilai leukosit. Nilai leukosit pada penelitian ini lebih rendah dibandingkan nilai normal leukosit. Nili leukosit yang lebih rendah pada penelitian ini didugadipengaruhi oleh umur anak ayam pada saat pengamatan. Pengamatan nilai leukosit penelitian ini dilakukan pada umur 2 minggu yang menyebabkan nilai leukosit masih relatif lebih rendah.. Hal ini sesuai dengan pendapat Guyton dan Hall (2006) yang menyatakan bahwa konsentrasi leukosit dipengaruhi oleh beberapa faktor dimana salah satunya adalah umur ternak. Selain dipengaruhi umur rendahnya nilai leukosit pada penelitian ini diduga karena tidak dilakukannya vaksinasi yang menyebabkan nilai leukosit cukup rendah. Siswanto et al. (2016) menyatakan bahwa vaksinasi pada ayam akan meningkatkan sel-sel leukosit sebagai 
akibat polifiresi sel leukosit untuk membentuk kekebalan tubuh.

Perbedaan konsentrasi IgY pada induk secara statistik tidak mempengaruhi presentase heterofil pada anak ayam yang dihasilkan, namun presentase heterofil pada anak ayam yang berasal dari induk dengan IgY rendah memiliki presentase heterofil cenderung tinggi.
Hal ini mengindikasi ayam dengan konsentrasi IgY rendah melindungi diri dengan meningkatkan kadar heterofil didalam tubuh. Kondisi ini disebabkan ayam dengan konsentrasi IgY rendah cenderung lebih mudah terserang agen infeksi sehingga heterofil sebagai garis pertahanan tubuh pertama lebih tinggi kadarnya (Mitchell \& John, 2008).

Tabel 2. Gambaran sel darah putih anak ayam sentul selama penelitian

\begin{tabular}{|c|c|c|c|}
\hline \multirow{2}{*}{ Parameter } & \multicolumn{2}{|c|}{ IgY induk } & \multirow{2}{*}{ Standar } \\
\hline & Tinggi & Rendah & \\
\hline Leukosit $\left(10^{3} \mathrm{sel} \mathrm{mm}^{-3}\right)$ & $6.38 \pm 2.82$ & $7.48 \pm 2.86$ & $22.30-30.10^{1}$ \\
\hline Heterofil (\%) & $26.55 \pm 11.37$ & $31.73 \pm 15.94$ & $23.00-30.00^{1}$ \\
\hline Limfosit $(\%)$ & $70.50 \pm 11.70$ & $65.60 \pm 17.20$ & $63.00-73.00^{1}$ \\
\hline Monosit (\%) & $2.44 \pm 1.19$ & $2.33 \pm 1.11$ & $0.00-3.00^{1}$ \\
\hline Eusinofil (\%) & $0.50 \pm 0.51$ & $0.33 \pm 0.48$ & $1.00-6.00^{1}$ \\
\hline Basofil $(\%)$ & - & - & - \\
\hline
\end{tabular}

Sumber: ${ }^{1}$ Turcu et al. (2011)

Hasil analisis statistik terhadap nilai limfosit menunjukan bahwa perbedaan konsentrasi IgY pada induk tidak mempengaruhi nilai limfosit. Namun bila diperhatikan, anak ayam yang berasal dari induk dengan IgY tinggi memiliki nilai limfosit lebih tinggi dibanding anak ayam yang berasal dari induk dengan IgY rendah. Hal ini disebabkan, limfosit merupakan sel leukosit yang berfungsi sebagai tempat pembentukan antibodi (IgY) (Letran et al., 2011) sehingga nilai IgY yang tinggi pada induk diduga menyebabkan nilai limfosit juga tinggi. Limfosit yang tinggi ini mengindikasikan ayam memiliki sistem kekebalan tubuh yang lebih baik.

Presentase basofil pada anak ayam kedua perlakuan menunjukkan, tidak terdeteksi adanya basofil di dalam darah. Walaupun basofil tidak ditemukan dalam penelitian ini, tidak berarti bahwa ayam tidak mensintesis basofil di dalam tubuhnya. Hal tersebut disebabkan basofil merupakan leukosit yang jumlahnya paling rendah dari seluruh leukosit yang ada di dalam darah (Ulupi et al., 2014).

Eusinofil diproduksi pada saat infeksi parasit dan pada saat terjadinya reaksi alergi (Guyton \& Hall, 2006). Persentase eosinofil yang diperoleh pada penelitian ini berada dibawah kisaran yang normal. Rendahnya presentase eusinofil pada kedua perlakuan tidak dapat diartikan anak ayam dalam kondisi tidak normal. Kondisi ini mengindikasi bahwa ayam tidak terinfeksi parasit ataupun reaksi alergi selama pemeliharaan

Rasio H/L merupakan indikator adanya stres panas. Altan et al. (2000), melaporkan bahwa cekaman stres menyebabkan rasio $\mathrm{H} / \mathrm{L}$ meningkat. Meningkatnya rasio $\mathrm{H} / \mathrm{L}$ disebabkan hormon yang meningkatkan stres disekresikan oleh kelenjar adrenal akan meningkatkan rasio H/L (Gudev et al., 2011). Penelitian ini memperlihatkan bahwa anak ayam yang berasal dari induk dengan konsentrasi IgY rendah memiliki rasio $\mathrm{H} / \mathrm{L}$ lebih tinggi dibanding anak ayam yang berasal dari induk dengan konsentrasi IgY tinggi. Hasil ini mengindikasikan anak ayam yang berasal dari induk dengan konsentrasi IgY rendah lebih mudah terpapar stres panas.

Stres panas merangsang hypothalamicpituitary-adrenal cortical system, sehingga hipotalamus menghasilkan corticotrophin realising factor (CRF). CRF ini menyebabkan kelenjar pituitari melepaskan hormon ACTH (adrinoccorticatropin hormone) sehingga jaringan korteks adrenal menghasilkan hormon kortikosteroid yang menurunkan kadar limfosit. Penurunan kadar limfosit ini menyebabkan menurunnya sistem kekebalan sehingga terjadi peningkatan rasio heterofil/limfosit dalam darah (Davis et al., 2008). Hasil penelitian ini menunjukan bahwa anak ayam yang berasal dari induk dengan konsentrasi IgY tinggi lebih tahan terhadap cekaman panas, sehingga cocok dipelihara di Indonesia yang merupakan negara tropis 
dengan suhu relatif tinggi dan dapat dijadikan sebagai salah satu indikator bibit.

\section{KESIMPULAN}

Perbedaan konsentrasi IgY tidak mempengaruhi gambaran darah anak ayam yang dihasilkan, namun pengamatan terhadap rasio $\mathrm{H} / \mathrm{L}$ menunjukan bahwa anak ayam yang berasal dari induk dengan konsentrasi IgY lebih tahan terhadap stres panas.

\section{DAFTAR PUSTAKA}

Altan, O., A. Altan, M. Cabuk, \& H. Bayraktar. 2000. Effects of heat stress on some blood parameters in broiler. J Vet Anim Sci. 24: 145-148.

Banergee, S. K., B.C. Patra BC, P. Bandeypahyay \& A. Teway. (2002). Changes of blood parameter in carp Catla catla. Journal of Aquatic Biology, 17(11): 79-84.

Davis, A.K., D.L. Ma ney, \& J.C. Maerz. 2008. The use of leukocyte profiles to measure stress in vertebrates: a review for ecologists. Funct Ecol. 22(5):760-772.

Gudev, D., S. Popova-Ralcheva, I. Ianchev, \& P. Moneva. 2011. Effect of betaine and air ammoniaconcentration on broiler performance, plasma corticosterone level, lymphoid organ weights and some haematological indices. Biotech in Animal Husb. 27 (3):687-70.

Guyton, A.C. \& J.E. Hall. 1997. Buku Ajar Fisiologi Kedokteran. Irawati Setiawan, Penerjemah. EGC. Jakarta.

Letran, S.E., S.J. Lee, S.M. Atif, S. Uematsu, S. Akira, S.J. McSorley. 2011. TLR5 functions as an endocytic receptor to enhance flagellin-specific adaptive immunity. Eur J Immunol. 41(1):29-38.

Mitchell, E. B., J. Jhons. 2008. Avian hematology and related disorders. Vet clin North Am Exot Anim Pract. 11(3): 501-522

Rastogi, S.C. 2007. Essentials of Animal Physiology 4th Edition. New Age International. New Delhi.

Regar, N.M., R. Mutia, D.S Widhyari, \& S. H. Y. Kowel. 2013. Pemberian Pakan Kombinasi Herbal dengan Mineral Zink
Terhadap Performan Ayam Broiler yang Diinfeksi Escherichia coli. Jurnal Zootek 33:35-40.

Sastradipraja, D., S.H.S. Sikar, R. Wijayakusuma, T. Ungerer, A. Maad, H. Nasution H, R. Suriawinata \& R. Hamzah. 1989. Penuntun Praktikum Fisiologi Veteriner. Pusat Antar Universitas Ilmu Hayati. Institut Pertanian Bogor. Bogor.

Setyawati, M. P., N. Ulupi, C. Sumantri, \& S. Murtini. 2019. Production performance, reproduction and immunity of sentul hens at different IGY concentrations. Buletin Peternakan. 43(1):1-5.

Turcul, D., M. Oporanul, P. Grigorescu1 \& M. Roman. 2011. Studies on hematological parameters in broiler chicken treated with amoxidem 50\%. Medicamentul Veteriner. 5(1):93.

Ulupi, N. Muladno, C. Sumantri, I.W.T. Wibawan. 2014. Study of kampong chiken resistence against Salmonella entriditis using TL4R gene as marker. Int J Poult Sci. 13(8):467-472.

Ulupi, N, \& T. T. Ihwantoro. 2014. Gambaran Darah Ayam Kampung Dan Ayam Petelur Komersial Pada Kandang Terbuka Di Daerah Tropis. Jurnal Ilmu Produksi dan Teknologi Hasil Peternakan. 2(1):219-223.

Weiss, D.J., \& K.J. Wardrop. 2010. Veterinary Hematology. Sixth Edition. WileyBlackwell Publishing. Singapore.

Wientarsih, I.,S.D. Widhyari, \& T. Aryanti. 2013. Kombinasi imbuhan herbal kunyit dan zink dalam pakan sebagai alternatif pengobatan kolibasilosis pada ayam pedaging. Jurnal Veteriner. 14(3): $327-$ 334.

Yokoi. K., J. Kobayashi, M. U. Sakai, \& M. Tsuji. 2002. Sandwich ELISA detection of excretory-secretory antigens of Toxocara canis larvae using a specific monoclonal antibodi. Southeast Asian J. Trop. Med. Public Health. 33(1):33-37. 